\title{
Hubungan Self Confidence Dengan Adversity Quotient Pada Mahasiswa Pasca Drop Out di Universitas Trunojoyo Madura
}

\author{
Illa Ilmiah ${ }^{1}$, Triyo Utomo ${ }^{2}$ \\ ${ }^{1}$ Prodi Psikologi \\ Universitas Trunojoyo Madura \\ 1Illa,ilmiyah26@gmail.com \\ 2triyo.utomo@yahoo.com
}

\begin{abstract}
The purpose of this study is to examine the relationship between self confidence with adversity quotient of post-drop out students at Universitas Trunojoyo Madura. The hypothesis is that there is a relationship between self confidence and adversity quotient in post-drop out students at Universitas Trunojoyo Madura. The research method is a quantitative approach. The number of participants was 130 people with a purposive sampling technique. The scale used is a scale of self confidence and adversity quotient. Data analysis using the Spearman Rank and analyzed using the SPSS 23.0 program. The results show the correlation is 0.844 (significance level $0.000<0.05$ ) which means the level of relationship between variables is very strong. It illustrates that there is a positive relationship between self confidence and adversity quotient in post-drop out students at Universitas Trunojoyo Madura. In other words, the hypothesis is accepted.
\end{abstract}

Key Words: Self Confidence, Adversity Quotient, Students, Drop Out

\begin{abstract}
Abstrak
Tujuan dari penelitian ini yaitu menguji hubungan self confidence dengan adversity quotient mahasiswa pasca drop out di Universitas Trunojoyo Madura. Adapun hipotesisnya adalah ada hubungan antara self confidence dengan adversity quotient pada mahasiswa pasca drop out di Universitas Trunojoyo Madura. Metode penelitiannya adalah dengan pendekatan kuantitatif. Jumlah partisipannya sejumlah 130 orang dengan teknik purposive sampling. Skala yang digunakan adalah skala self confidence dan adversity quotient. Analisis data memakai Spearman Rank serta dianalisis menggunakan program SPSS 23.0. Hasil menunjukkan korelasinya adalah sebesar 0,844 (taraf signifikansi $0.000<0,05$ ) yang artinya tingkat hubungan antar variabel adalah sangat kuat. Hal itu menggambarkan ada hubungan positif antara self confidence dengan adversity quotient pada mahasiswa pasca drop out di Universitas Trunojoyo Madura. Dengan kata lain, hipotesis diterima.
\end{abstract}

Kata Kunci: Self Confidence, Adversity Quotient, Mahasiswa, Drop Out Pendahuluan 
Statistika perguruan tinggi (2017) mengemukakan bahwa mahasiswa adalah peserta didik pada jenjang pendidikan tinggi. Gunawati, dkk (2006) manyatakan bahwa mahasiswa masuk kategori remaja akhir dan telah tergolong dewasa awal. Adapun usianya mulai 18 sampai 21 tahun serta 22 sampai 24 tahun. Mahasiswa yang telah memasuki usia dewasa membuatnya mempunyai kewajiban terhadap tugas perkembangan. Tugas perkembangan dewasa awal menurut Santrock (dalam Hidayah, 2012) adalah menentukan keputusan terkait karir, keluarga, hubungan, serta gaya hidup. Harapan keluarga dan masyarakat untuk mahasiswa di masa mendatang diperlukan kontribusinya untuk meneruskan negara ini. SDM yang memiliki kualitas adalah modal penting untuk bangsa dan negara (Arham,dkk 2017).

Kenyataannya tidak semua mahasiswa berhasil menyelesaikan tuntutan tanggung jawabnya dalam bidang akademik di perguruan tinggi. Bentuk dari tidak berhasilnya mahasiswa pada studi perguruan tinggi adalah ketika mengalami $d r o p$ out. Istilah drop out umumnya digunakan untuk menggambarkan situasi siswa yang mendaftar di lembaga pendidikan tertentu dan keluar atau dikeluarkan tanpa memperoleh ijazah atau lulus ujian akhir mereka (Bungau, dkk, 2017). Statistika perguruan tinggi (2017) menjelaskan bahwa di Indonesia sendiri jumlah mahasiswa yang terdaftar sebanyak 6.924.511 dan mahasiswa yang di drop out adalah sebanyak 195.176 dengan presentase drop out sebanyak 2,8\%. Persentase drop out tertinggi mahasiswa di Indonesia terdapat di Bengkulu yaitu 8,24\%. Apabila diangkakan sejumlah 3.947 dari total 47.913 mahasiswa pada tahun 2017. Posisi kedua diduduki oleh Kepulauan Riau yaitu di angka 7,5\% mahasiswa yang studinya putus di tengah jalan. Jumlahnya ada 3.470 kasus. Berdasarkan data tersebut, 4\% atau sejumlah 162 merupakan mahasiswa PTN (Perguruan Tinggi Negeri). Jawa Timur menduduki posisi selanjutnya dengan angka drop out 4,54\% yaitu 38.317 dari total 844.675 mahasiswa. Prosentase putus kuliah untuk kategori kampus negeri di Jawa Timur adalah sebesar 0,40\%. Sedangkan prosentase mahasiswa drop out di Universitas Trunojoyo Madura yang merupakan salah satu kampus negeri di Jawa Timur adalah sebesar 0,51\%. Angka tersebut lebih besar 0,11\%.

Menurut Arham, dkk (2017) mahasiswa drop out yang dapat menerima keadaannya bisa memikul tanggung jawab melalui langkah yang dilakukan, yakin 
terhadap diri sendiri serta percaya terhadap apa yang bisa dilakukannya. Memperoleh pengalaman drop out mahasiswa dapat berpikir lebih jernih untuk mengambil tindakan dan melaksanakan berbagai langkah untuk berikutnya. Namun kondisi tersebut berlawanan dengan fakta yang ada pada masyarakat. Beratnya mengatasi beban karena drop out dari perguruan tinggi memicu stress dan bahkan depresi sehingga memunculkan perilaku-perilaku maladaptif. Larsen (dalam Donggeun \& Seoyong, 2018) menggambarkan konsekuensi yang signifikan bagi individu karena drop out, drop out memberi dampak psikologis dan fisik. Mahasiswa dapat menderita depresi yang timbul dari perasaan tidak mampu dan keraguan diri, dan semua yang berhubungan dengan drop out. Selain itu, mereka akan menyadari membuang-buang sumber daya pibadi, usaha, waktu, dan uang.

Perlu adanya sebuah kemampuan untuk menghadapi berbagai kesulitan tersebut khususnya untuk melanjutkan kehidupan. Berbagai masalah dapat menjadi sebuah tantangan yang akan berubah jadi kesempatan guna melaksanakan transformasi ke arah positif bagi mereka yang tahu dan paham (Stoltz, 2000). Akan tetapi, sebagian besar individu tidak melanjutkannya ketika potensi-potensinya belum digunakan guna mengatasi hambatan-hambatan yang menimpanya. Adversity quotient (AQ) adalah apa yang mampu dilakukan individu untuk mengatasi berbagai persoalan, rintangan atau hambatan yang dihadapinya, untuk selanjutnya merubahnya jadi sebuah kesempatan berhasil serta sukses (Stoltz, 2000). AQ yang meningkat jadi hal signifikan sehingga dapat membenahi daya tahan individu guna mengatasi bermacam-macam kondisi, yang meliputi kondisi senang atau susah.

Keyakinan merupakan salah satu faktor yang juga berpengaruh terhadap terbentuknya AQ (Stoltz, 2000). Faktor intenal AQ salah satunya adalah keyakinan, dan menurut Lauster individu mempunyai keyakinan yang merupakan aspek percaya diri. Menurut De Anglis (2003) keyakinan akan diri membentuk sebuah rasa percaya terhadap diri. Kepercayaan diri berasal dari diri individu, terkait tekad sesorang guna melaksanakan diharapkan serta dibutuhkan untuk melalui tahap kehidupan. Guna menciptakan percaya diri sebenarnya dimulai dari rasa yakin akan diri, terkait upaya seseorang menghadapi berbagai rintangan hidup. Dampaknya, individu bisa melakukan tindakan dalam rangka mengatasi berbagai rintangan. 
Kepercayaan diri kemudian menjadi faktor yang menentukan sukses tidaknya individu. Berbagai orang hebat bisa meraih sukses di kehidupannya karena mempunyai ciri rasa percaya diri seperti yang dibahas Spancer (dalam Pangestianto, 2018) berikut ini. Rasa percaya diri adalah bentuk umum yang dipunyai individu dengan kinerja superior (superior performer). Rasa percaya diri sebagai yang menetukan keberhasilan individu kemudian menjadi relevan bagi AQ karena tujuan dari AQ sendiri adalah mengubah hambatan menjadi peluang kesuksesan. Leonard \& Amanah (2014) menyatakan bahwa rasa percaya diri memiliki peran signifikan guna mengimplementasikan potensi individu. Individu yang mempunyai derajat keyakinan terhadap diri yang tinggi bisa menciptakan kepercayaan terhadap dirinya terkait kapasitas supaya tidak mudah menyerah saat menemui persoalan. Srijanti, dkk (2007) mengungkapkan bahwa beberapa strategi sukses salah satunya yakni sikap percaya diri atau self confidence.

Kepercayaan diri merupakan sebuah bagian dari pribadi diri yang sangat signifikan untuk dimiliki oleh setiap orang. Percaya diri atau self confidence merupakan trait yang dapat menampilkan kemampuan kinerja secara optimal. Pendayagunaan kepercayaan diri berarti membangun kepercayaan diri menjadi kekuatan yang mampu mengolah cara berfikir seseorang dan orang itu dapat bertindak untuk menjadi lebih baik dari sebelumnya. Seseorang dalam mencapai kesuksesan harus memiliki rasa percaya diri atau keyakinan bahwa dirinya akan lebih maju. Tiap individu mempunyai kemampuan, akan tetapi individu yang memiliki kemauan untuk berhasil, masih terbatas. Banyak pula orang yang tidak mengetahui cara mendayagunakan kemampuan atau potensi diri yang dimilikinya (Srijanti.,dkk, 2007). Menurut Hidayat (dalam Nurkholifah, dkk, 2018) sikap percaya diri bisa diinterpretasikan laksana perjuangan individu untuk menyelesaikan persoalan yang ada.

Adapun penelitian lain yang dilaksanakan Pangestianto (2018), yang berjudul "Hubungan Kepercayaan Diri Dengan Adversity Quotient Karyawan Pada Frontliner BRI Tulungagung”, mengungkap bahwa ada hubungan yang signifikan antara percaya diri dengan adversity quotient.

Pada konteks penelitian ini, penulis akan meneliti korelasi antara self confidence dengan adversity quotient mahasiswa pasca drop out, harapannya 
mahasiswa pasca drop out dapat meningkatkan self confidence atau kepercayaan diri sehingga memunculkan karakteristik pribadi yang dapat keluar dari tekanan dan kesulitan karena drop out dengan mengoptimalkan kemampuan mengubah kesulitan menjadi sebuah tantangan untuk diselesaikan atau bisa disebut adversity quotient.

\section{Landasan Teori}

\section{Kepercayaan Diri}

Kepercayaan diri adalah bagian dari aspek kepribadian yang terwujud dalam keyakinan terhadap kemampuan individu sehingga orang lain tidak memiliki pengaruh serta bisa beraktivitas menurut keinginan, senang, berpandangan positif, cukup pengertian dan konsekuen (Lauster dalam Ghufron \& Risnawita, 2017). Lauster memberikan tambahan bahwa rasa percaya diri terkait dengan kapasitas melaksanakan suatu hal dengan baik. Pendapat tersebut menjadikan seseorang tidak dapat menjelma jadi individu yang memiliki rasa percaya diri yang murni. Seperti apapun kecakapan individu hanya spesifik terhadap sesuatu yang bisa dilaksanakan secara optimal serta sebanyak kemahiran yang bisa dilakukan.

\section{Aspek-Aspek Self Confidence}

Reliabilitas kedua alat ukur yang dipakai ini juga memiliki skor yang cukup tinggi. Untuk alat ukur Grit yakni $r=0.749$. Sedangkan untuk OCB, peneliti mendapatkan $r=0.790$. Namun, peneliti juga mencoba untuk melihat per dimensi, yakni $r=0.790$ untuk OCBI dan $r=0.600$ untuk OCBO dengan tetap dapat mempertahankan 2 aitem. Hal ini lebih baik dibandingkan ketika peneliti mencoba mengukur reliabilitas secara keseluruhan yang membuat seluruh aitem di OCBO gugur.

Ada sejumlah bagian rasa percara diri yang ada pada diri individu seperti yang dinyatakan Lauster (dalam Ghufron \& Risnawati, 2017) seperti di bawah ini:

a. Kepercayaan terhadap kapasitas diri Merupakan pandangan positif individu terhadap diri terkait pemahaman serius terhadap yang perilakunya.

b. Optimistis 
Sikap positif seseorang yang selalu berpendapat baik dalam menghadapi segala hal tentang dirinya, ekspektasi serta kemampuannya.

c. Obyektif

Individu yang memiliki kepercayaan diri melihat persoalan berdasarkan situasi sesungguhnya, bukan didasarkan subyektivitas pribadi.

d. Mempunyai rasa tanggung jawab

Kesanggupan individu guna menerima berbagai hal yang sudah menjadi tanggung jawabnya.

e. Logis dan Berdasakan Fakta

Analisa terhadap persoalan, sesuatu hal, suatu kejadiaan memakai pandangan yang konsisten dengan rasional serta sesuai realitas.

\section{AQ (Adversity Quotient)}

AQ adalah suatu kapasitas individu dalam melihat kesulitan dan mengolah kesukaran tersebut menggunakan intelektualitas yang dipunyai yang membuatnya jadi tantangan guna diselesaikan (Stoltz, 2000). AQ adalah intelektualitas yang bisa menyampaikan gambaran kepada seseorang terkait sejauh mana individu bisa mempertahankan diri mengatasi hambatan serta dapat memecahkannya. Bagi individu yang dapat menghadapi hambatan dan individu yang bisa menggapai harapannya terkait unjuk kerja dan potensi.

\section{Dimensi-Dimensi AQ}

$A Q$ memiliki 4 dimensi. Empat dimensi itu yaitu:

a. Control $(C)$

Pada umumnya kendali (Control) bersifat internal atau individual. Dimensi ini menjelaskan sejauh mana individu merasakan bisa menghadapi hambatan dalam setiap situasi. Bertambah besar kontrol yang dipunyai maka bertambah besar juga probabilitas individu supaya bisa menghadapi kesulitan dan mampu mencari penyelesaian. Demikian sebaliknya, jika semakin rendah kendali, akibatnya seseorang menjadi tidak berdaya menghadapi kesulitan dan mudah menyerah.

b. Origin \& Ownership (O2) 
O2 merupakan singkatan "Origin" (asal mula) serta "Ownership" (kepemilikan). Pada dimensi ini akan menyampaikan pertanyaan terkait siapa yang memunculkan awal hambatan serta sampai seberapa jauh seorang individu membenarkan akibat dari kesulitan itu sendiri. Origin akan menjelaskan bagaimana individu merespon sumber-sumber kesulitan yang terjadi itu berasal dirinya atau ada faktor-faktor lainnya. Sedangkan ownership menjelaskan bagaimana seseorang menyerap dampak dari kesulitan, apapun yang menyebabkan serta mencari jalan keluar atas kesulitan tersebut atau tidak mengakui berbagai dampak atas kesulitan apapun yang menyebabkannya.

c. $\operatorname{Reach}(\mathrm{R})$

Reach atau jangkauan, dimensi ini merupakan bagian dari Adversity Quotient yang mempersoalkan terkait sampai seberapa jauh persoalan akan menyentuh elemen lain dari diri seseorang. Jangkauan mempunyai arti sampai seberapa jauh hambatan akan sampai ke berbagai aspek kehidupan individu atau membatasi kesulitan pada masalah yang dihadapi. Bertambahnya efektivitas untuk mempertahankan cakupan kesukaran, maka individu juga lebih mudah sehingga ketika memiliki kesulitan dalam suatu masalah maka tidak merambat pada aspek yang lain dari kehidupan seseorang.

d. Endurance (E)

Endurance atau daya tahan merupakan dimensi keempat dalam Adversity Quotient yang menjelaskan berapa lama seseorang bertahan menghadapi masalah. Apakah masalah tersebut akan berlangsung lama atau hanya bersifat temporer, terjadi secara cepat, dan rendah persentasenya untuk terjadi lagi.

\section{Metode Penelitian}

Penelitian memakai pendekatan studi hubungan kuantitatif. Azwar (2017) memberikan penjelasan bahwa riset yang memakai metode kuantitatif memberikan tekanan analisisnya pada data-data kuantitatif (angka). Sedangkan penelitian korelasional menurut Periantalo (2016) adalah riset yang ingin meneliti korelasi 
diantara variabel. Apakah memiliki hubungan atau tidak, jika berhubungan bagaimana kekuatan hubungan serta arah hubungan tersebut. Bentuk skala pengukuran dalam penelitian ini ada dua skala yaitu : (1) skala perbedaan semantik atau semantic differensial yaitu pada skala adversity quotient (variabel Y) dari Stoltz yang dinamakan ARP (Adversity Response Profile) dan disusun berdasarkan aspek CO2RE yaitu control (kendali diri), origin dan ownership (asal usul dan pengakuan diri), reach (jangkauan) dan endurance (daya tahan). Skala ini terdiri dari 15 butir pernyataan dengan menggunakan rentang 1 s.d 5 alternatif pilihan jawaban. (2) skala likert untuk variabel X yaitu skala self confidence. Skala self confidence disusun berdasarkan aspek menurut Lauster dalam Ghufron \& Risnawati (2012) yaitu keyakinan akan kemampuan diri, optimis, objektif, bertanggung jawab serta rasional dan realistis. Skala ini terdiri dari 47 butir pernyataan dengan empat alternatif pilihan jawaban.

Populasi dalam penelitian ini adalah mahasiswa pasca drop out kategori habis masa studi di Universitas Trunojoyo Madura sebanyak 254 orang dengan sampel sebanyak 130 responden. Teknik sampling dalam penelitian ini menggunakan teknik sampling purposive yakni teknik penentuan sampel dengan pertimbangan tertentu (Sugiyono, 2015).

Data yang terkumpul kemudian dilakukan uji validitas dan uji reliabilitas. Pengukuran validitas dan reliabilitas penelitian ini menggunakan percobaan (try out) terlebih dahulu. Kemudian hasil yang didapatkan dapat langsung digunakan sebagai hasil dari penelitian. Setelah melewati uji validitas dan reliabilitas kemudian dilanjutkan melakukan uji asumsi: (1) Uji normalitas dengan menggunakan Kolmogorov-Smirnov, (2) Uji Linieritas dengan menggunakan Test for Linearity. Analisis data pada penelitian ini dilanjutkan dengan pengujian hipotesis menggunakan teknik uji korelasi Spearman Rank dengan bantuan SPSS 23.0.

\section{Hasil dan Pembahasan}

Hasil

Uji validitas pada penelitian ini dilakukan dua kali dengan melakukan uji coba. Uji coba pertama dilakukan pada 50 mahasiswa drop out yang setara dengan 
kelompok target penelitian, kemudian selanjutnya disebarkan kepada 130 responden mahasiswa drop out yang sesuai kriteria dengan jumlah butir pernyataan sebanyak 47 item pada skala self confidence dan 15 item pada skala adversity quotient. Skala self confidence memperoleh rentang angka koefisien korelasi 0,204-0,575 dengan nilai cronbach's alpha 0,890, oleh sebab itu dapat dinyatakan bahwa skala self confidence memiliki nilai reliabel tinggi. Sedangkan skala adversity quotient memperoleh rentang angka koefisien korelasi 0,397-0,625 dengan nilai cronbach's alpha 0,811, oleh sebab itu dapat dinyatakan bahwa skala adversity quotient memiliki nilai reliabel tinggi. Uji normalitas dalam penelitian ini menunjukkan bahwa skala self confidence dan adversity quotient tidak berdistribusi normal, dilihat dari hasil tes normalitas, pada kolom Kolmogorov-Smirnov mendapatkan nilai Sig. 0,13 untuk variabel self confidence dan nilai Sig. 0,000 untuk variabel adversity quotient. Pada tabel anova menunjukkan bahwa uji linieritas diperoleh nilai signifikansi 0,408 yang lebih besar dari 0,05 maka dapat disimpulkan bahwa asumsi linier dalam penelitian ini terpenuhi. Selanjutnya data di uji korelasi dengan Spearman-Rank karena untuk melakukan korelasi SpearmanRank syarat-syaratnya adalah salah satu atau kedua data variabel terdistribusi tidak normal dan kedua data variabel menggunakan level data interval atau rasio (Natanael, 2013). Berikut ini merupakan hasil uji korelasi Spearman-Rank antara variabel self confidence dan adversity quotient:

Tabel 1

Hasil Uji Korelasi Spearman Rank

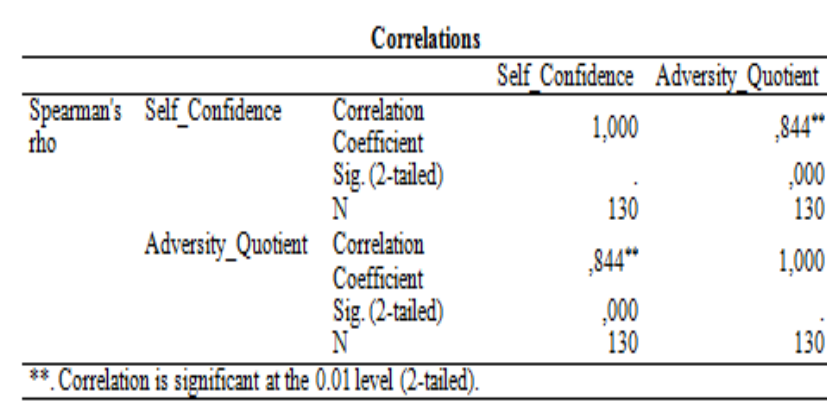

Berdasarkan output yang diperoleh diketahui bahwa besarnya korelasi antara variabel self confidence dengan adversity quotient 0,844 dengan signifikansi $0,000<0,05$ maka ada hubungan yang signifikan antara variabel self confidence 
dengan adversity quotient. Dari hasil nilai koefisien korelasi (r) sebesar 0,844 dapat diidentifikasi bahwa koefisien korelasi 0,844 memiliki tingkat hubungan yang sangat kuat.

\section{Pembahasan}

Dari temuan pada penelitian ini diperoleh informasi bahwa pengujian hipotesis hasil korelasi koefisien analisis data dari hasil analisis uji Spearman-Rank tersebut diperoleh koefisien korelasi 0,844 artinya besar korelasi antara self confidence dan adversity quotient berada pada interval 0,81-0,99 berdasarkan tabel interpretasi koefisien korelasi menurut Periantalo (2016). Maka dapat dilihat bahwa koefisien korelasi 0,844 memiliki tingkat hubungan yang sangat kuat. Hubungan kedua variabel signifikan karena angka signifikansi sebesar 0,000 $<0,05$ maka hipotesis diterima, yang artinya terdapat hubungan antara self confidence dengan adversity quotient pada mahasiswa pasca drop out di Universitas Trunojoyo Madura.

Berdasarkan hasi uji korelasi Spearman-Rank angka koefisien korelasi sebesar 0,844 maka menunjukkan bahwa arah hubungan yang terjadi adalah positif (+). Hal tersebut menunjukkan bahwa semakin tinggi skor self confidence maka semakin tinggi skor adversity quotient. Semakin rendah skor self confidence maka semakin rendah skor adversity quotient. Mahasiswa pasca drop out di Universitas Trunojoyo Madura yang mempunyai kepercayaan diri yang baik akan memiliki adversity quotient yang baik pula, mahasiswa pasca drop out di Universitas Trunojoyo Madura yang memiliki self confidence yang rendah akan memiliki adversity quotient yang rendah pula. Hasil penelitian ini, sesuai dengan hasil penelitian Leonard dan Amanah (2014) yang menyebutkan bahwa kepercayaan diri berfungsi penting untuk mengaktualisasikan potensi yang dimiliki. Seseorang yang memiliki tingkat kepercayaan yang tinggi dapat membentuk keyakinan pada dirinya tentang kemampuan untuk pantang menyerah dalam menghadapi masalah yang ada.

Menurut Hakim (2002) pemahaman untuk merespon positif terhadap kelemahan yang dimiliki agar tidak menimbulkan rasa rendah diri atau rasa sulit menyesuaikan diri serta pemahaman seseorang terhadap kelebihan yang dimiliki dapat menghasilkan kepercayaan besar supaya dapat melakukan berbagai upaya melalui upaya penggunaan keunggulannya sehingga bisa membentuk kepercayaan 
diri yang kuat pula guna melalui kehidupan dengan memberdayakan berbagai keunggulan yang terdapat dalam dirinya. Sehingga dengan adanya self confidence atau kepercayaan diri mahasiswa pasca drop out yang kuat akan menjadikan mahasiswa pasca drop out dapat menghadapi kesulitan-kesulitan dalam hidupnya. Suatu kemampuan seseorang dalam memahami, menghadapi dan menyelesaikan segala permasalahan dalam hidup untuk meraih kesuksesan dengan segala potensi yang dimiliki, cara berfikir dan bersikap terhadap kesulitan-kesulitan kemudian diartikan sebagai adversity quotient. Menurut Stolzt (2000) adversity quotient dapat memberikan gambaran kepada individual berkaitan dengan seberapa jauh individu mampu bertahan menghadapi kesulitan dan mampu untuk mengatasinya. Siapa yang mampu mengatasi kesulitan dan siapa yang akan hancur, siapa yang akan melampaui harapan-harapan atas kinerja dan potensi individual serta siapa yang akan gagal serta siapa yang akan menyerah dan siapa yang akan bertahan.

Salah satu faktor yang mempengaruhi terbentuknya AQ adalah keyakinan. Keyakinan merupakan salah satu faktor intenal AQ, dan menurut Lauster keyakinan merupakan salah satu aspek yang ada pada individu dengan kepercayaan diri positif. Menurut De Anglis (2003) keyakinan akan diri membentuk sebuah rasa percaya diri. Percaya diri itu berawal dari diri sendiri, bagaimana tekad sesorang untuk melakukan yang di inginkan dan dibutuhkan dalam menjalani proses kehidupan. Untuk dapat membentuk kepercayaan diri pada dasarnya berawal dari keyakinan diri sendiri, bagaimana seseorang dapat menghadapi segala tantangan dalam kehidupan, sehingga mampu berbuat sesuatu untuk menghadapi segala tantangan yang ada.

Pangestianto (2018) menambahkan bahwa individu yang memiliki kepercayaan diri tinggi pada dasarnya akan selalu bekerja keras dalam mencapai tujuan. Sifat tak mudah putus asa pada seorang pekerja keras tentu sesuai dengan adversity quotient yaitu dimana seseorang mampu bertahan dalam situasi yang sulit dan selalu berusaha memecahkannya. Pernyataan diatas sesuai dengan teori Stoltz (2000) bahwa seseorang yang memiliki adversity quotient akan berjuang menghadapi dan mengatasi masalah dan kesulitan dalam hidupnya. Penelitian lain yang dilakukan oleh Mustika, Yurniwati dan Hakim (2018) menunjukkan bahwa self confidence dan adversity quotient secara bersama-sama memiliki hubungan 
dengan kemampuan pemecahan masalah. Bahwa kemampuan untuk menyelesaikan permasalahan dapat dipengaruhi oleh kepercayaan terhadap kemampuan diri yang muncul dari suatu proses yang positif dan dapat juga dilihat dari daya juang atau kegigihan yang dapat mendorong seseorang untuk mengeluarkan kemampuannya dalam menyelesaikan permasalahan.

\section{Kesimpulan dan Saran}

\section{Kesimpulan}

Penelitian ini membuktikan ada hubungan antara self confidence dengan adversity quotient pada mahasiswa pasca drop out di Universitas Trunojoyo Madura dengan hasil uji korelasi Spearman Rank menunjukkan $\mathrm{P}=0,000(\mathrm{P}<0,05)$. Penelitian ini juga menghasilkan nilai koefisien korelasi sebesar 0,844 yang berarti korelasi sangat kuat. Hal tersebut menunjukkan bahwa koefisien korelasi bersifat positif yang berarti koefisien korelasi ini menunjukkan adanya hubungan yang searah, artinya semakin tinggi self confidence maka semakin tinggi adversity quotient. Dapat disimpulkan bahwa korelasi antara self confidence dengan adversity quotient sangat kuat, signifikan dan searah.

\section{Saran}

Berdasarkan hasil penelitian yang telah diperoleh, maka peneliti memberikan saran kepada beberapa pihak terkait yang dapat dijadikan bahan pertimbangan bagi yang membutuhkan serta diharapkan dapat memberi manfaat. Adapun saran tersebut adalah sebagai berikut:

a. Subyek

Hasil penelitian ini menunjukkan bahwa ada hubungan antara self confidence dengan adversity quotient pada mahasiswa pasca drop out di Universitas Trunojoyo Madura. Oleh sebab itu bagi mahasiswa pasca drop out di Universitas Trunojoyo Madura khususnya dengan self confidence dan adversity quotient rendah dan sedang diharapkan dapat meningkatkan self confidence atau kepercayaan diri agar dari peningkatan self confidence tesebut juga memacu timbulnya adversity quotient untuk dapat berjuang mengatasi segala kesulitan dan tantangan serta mewujudkan kesuksesan. Sedangkan bagi mahasiswa pasca drop out di Universitas 
Trunojoyo Madura yang sudah memiliki self confidence dan adversity quotient tinggi dapat mempertahankannya.

b. Keluarga dan Masyarakat

Keluarga dan masyarakat diharapkan tidak menjadi pihak yang akan semakin membuat mahasiswa pasca drop out di Universitas Trunojoyo Madura semakin rendah diri dengan keadaannya. Sehingga mahasiswa pasca drop out di Universitas Trunojoyo Madura dapat mengoptimalkan potensi lain yang ada dalam dirinya meskipun pernah mengalami kegagalan akademik serta dapat meningkatkan self confidence juga adversity quotient dalam dirinya.

c. Peneliti Selanjutnya

Peneliti selanjutnya yang tertarik untuk melanjutkan penelitian ini atau masalah yang hampir sama disarankan untuk melihat faktor lain dalam mengungkap masalah yang terjadi pada mahasiswa drop out.

\section{Daftar Pustaka}

Anglis, Barbara De. (2003). Percaya Diri Sumber Sukses dan Kemandirian. Jakarta: PT. Gramedia Pustaka Utama

Arham, S, Ahmad dan Ridfah. (2017). Penerimaan Diri Mahasiswa Drop Out. Makassar : Fakultas Psikologi Universitas Makassar ISSN: 2548-4044 Jurnal Psikoislamedia Volume 2, Nomor 1

Azwar, Saifuddin. (2017). Metode Penelitian Psikologi. Yogyakarta: Pustaka Belajar.

Bungau, C, Andrian Petru POP dan Andrian Borza. (2017) Dropout of first year undergraduate students: A case study of engineering students. Oradea, Romania : University of Oradea

Ghufron, M. N \& Risnawita. (2017). Teori-Teori Psikologi. Jogjakarta : Ar-Ruzz Media

Hakim, Thursan. 2002. Mengatasi Rasa Tidak Percaya Diri. Jakarta: Puspa Swara

Herawati, Netty \& Edi, F.R.S. (2016). Aplikasi Komputer Untuk Psikologi. Kepanjen: AE Publishing.

Hidayah, D. N. (2012) Persepsi Mahasiswa Tentang Harapan Orang Tua Terhadap Pendidikan Dan Ketakutan Akan Kegagalan. Semarang : Educational Psychology Journal Universitas Negeri Semarang 
Indonesia PDDikti Kemenristekdikti. (2017). Statistik Pendidikan Tinggi Tahun 2017 Pangkalan Data Pendidikan Tinggi. Jakarta : Pusdatin Iptek Dikti, Setjen Kemenristekdikti

Kementerian Riset Teknologi dan Pendidikan Tinggi Republik Indonesia. (2017, Desember). Statistik Pendidikan Tinggi 2017. Retrieved from academia.edu Web site: https://www.academia.edu/36759676/Statistik_Pendidikan_Tinggi_2017_St atistik_Pendidikan_Tinggi_2017?auto=download

Kim, Donggeun \& Kim, Seoyong. (2018). Sustainable Education: Analyzing the Determinants of University Student Dropout by Nonlinear Panel Data Models. Korea: Ajou University

Leonard \& Amanah, N. (2014). Pengaruh Adversity Quotient (AQ) dan Kemampuan Berpikir Kritis Terhadap Prestasi Belajar Matematika. Jakarta : Universitas Indraprasta PGRI

Nurkholifah, S, Toheri dan Widodo Winarso. (2018). Hubungan Antara Self Confidence Dengan Kemampuan Berfikir Kritis Siswa Dalam Pembelajaran Matematika. Cirebon : IAIN Syekh Nurjati

Pangestianto, B. (2018). Hubungan Kepercayaan Diri Dengan Adversity Quotient Karyawan (Pada Frontliner BRI Tulungagung). Malang : Universitas Muhammadiyah Malang

Periantalo, J. (2016). Penelitian Kuantitatif Untuk Psikologi. Yogyakarta : Pustaka Pelajar

Srijanti, Purwanto dan Primi Artiningrum. (2007). Etika Membangun Sikap Profesionalisme Sarjana. Yogyakarta : Graha Ilmu

Stoltz, P. G. (2000). Adversity Quotient : Mengubah Hambatan Menjadi Peluang. Jakarta : Grasindo

Stoltz, P. G. (2000). Adversity Quotient at Work: Finding Your Hidden Capacity for Getting Things Done. New York : HarperCollins Publishers

Sufren dan Natanael, Y. (2013). Mahir Menggunakan SPSS Secara Otodidak. Jakarta : PT. Elex Media Komputindo

Sugiyono. (2015). Metode Penelitian Kuantitatif Dan R\&D. Bandung: Alfabeta CV 
Hubungan Self Confidence Dengan Adversity Quotient... 